\title{
Comparison Between Open Pollinated Progenies and Hybrids Performance in Eucalyptus grandis and Eucalyptus urophylla
}

\author{
By O. Bison ${ }^{1)}$, M. A. P. RAmalho'), G. D. S. P. Rezende ${ }^{2)}$, A. M. Aguiar ${ }^{2)}$ and M. D. V. De Resende ${ }^{3)}$
}

(Received 21 ${ }^{\text {st }}$ December 2005)

\begin{abstract}
Summary
The cellulose industry in Brazil uses, mainly, hybrids between Eucalyptus grandis x E. urophylla. Not only the volume but also the wood density has great influence in the cellulose productivity, therefore a selection for both characteristics should be done as an alternative to increase the improvement program efficiency. The present work has been carried out with the objective of comparison between Open Pollinated progenies (OP) and hybrids performance in E. grandis and E. urophyl$l a$. To do so, 15 OP progenies of $E$. grandis, 15 OP progenies of $E$. urophylla, and 15 hybrids between $E$. grandis x $E$. urophylla, plus four controls were evaluated. The experiment was carried out from October to November 2001, in three sites, Aracruz and São Mateus, in the Espírito Santo State, and Caravelas, Bahia State, Brazil, in a $14 \times 14$ lattice design, involving the 49 treatments mentioned plus other progenies not considered in this article, with single tree plots and 40 replicates. Two years later the circumference at breast height $(\mathrm{CBH})$ and the basic wood density (BWD) were evaluated. The hybrids performance for $\mathrm{CBH}$ was higher, an average, $38,7 \%$ than the OP progenies for both species. Part of the heterosis in relation to parental means could be attributed to the inbreeding depression due to selfing that occurred in the OP progenies and the dominance controlling this character. For the BWD the hybrids performance was the same of the OP progenies. Since there was divergence between the parents, it can be inferred that dominance has no importance for this trait. The negative correlation between the $\mathrm{CBH}$ and the BWD could impair the simultaneous selection for both traits, depending on the wood basic density range used by the industry.
\end{abstract}

Key words: reciprocal recurrent selection, half-sib progenies, full-sib progenies, wood basic density, genetic correlation, genetic variance, heterosis, Eucalyptus.

\section{Introduction}

The genetic progress obtained with Eucalyptus in terms of wood volume in Brazil is remarkable. Therefore, to add gains is necessary the recombination of the best individuals which will have news genetic progress.

In Brazil, superior clones for cellulose production have been obtained mainly through inter-specific hybridization, via natural or controlled pollination, owing to the good performance for wood volume of some species in hybrid combinations. In this respect, the combination Eucalyptus grandis x E. urophylla is worth mentioning;

\footnotetext{
1) Universidade Federal de Lavras/DBI P. O. BOX 3037, CEP 37200-000. E-Mail: magnoapr@ufla.br

2) Aracruz Celulose S. A.

3) Empresa Brasileira de Pesquisa Agropecuária.
}

reciprocal recurrent selection involving these species will certainly lead to the identification of individuals superior to the existing ones in the short or medium term.

Since the objective of improvement programs is not only to improve the volume, but also the wood quality for cellulose production, doubts arise whether the use of reciprocal recurrent selection will be effective to improve these two traits simultaneously, since no heterosis was detected for wood density (Assis, 2000). On these grounds, the objective of this study was the comparison between OP progenies and hybrids performance in $E$. grandis and $E$. urophylla for traits of growth and wood density and to compile information that can help breeders at taking decisions on how to conduct recurrent selection programs, both reciprocal and within population, for these traits.

\section{Material and Methods}

Experiments were evaluated on three areas of the company Aracruz Celulose S. A., in the townships of Aracruz, ES: 19 $50^{\prime}$ lat S and 40 $12^{\prime}$ long W, São Mateus, ES: $18^{\circ} 36^{\prime}$ lat $\mathrm{S}$ and $40^{\circ} 01^{\prime}$ long W; Caravelas, BA $17^{\circ} 47^{\prime}$ lat $\mathrm{S}$ and $39^{\circ} 33^{\prime}$ long W.

To obtain the populations, the company selected 200 $E$. grandis and 200 E. urophylla trees and established a seed production orchard for each by means of clone propagation. A hundred-ninety-two progenies were obtained from these two orchards, 62 of which were $E$. grandis half-sibs, $68 \mathrm{E}$. urophylla half-sibs and 62 full-sibs of $E$. grandis x E. urophylla. For 15 full-sib progenies, the respective OP progenies of each population were available, while for 22 full-sib progenies only one of the parents was available. Four commercial clones were included in the trials as controls.

The experiments were established between October and November 2001, in a 14 x 14 lattice design with 40 replicates and single tree plots. The plants were spaced $3 \times 3 \mathrm{~m}$ and the commonly used management for commercial stands was applied in the experiments.

Two years after the implantation of the experiments the following data were collected: circumference at breast height $(\mathrm{cm})$ and penetration of pilodyn needle into the wood (mm).

Based on the pilodyn evaluation the basic wood density $\left(\mathrm{kg} . \mathrm{m}^{-3}\right)$ was estimated by the expression: Density = $615-11 *$ Pilodyn reading $\left(\mathrm{R}^{2}=0,6530\right)$. To establish this expression, 142 two-year-old trees of different eucalypt species had previously been evaluated with the pilodyn and the wood density had been determined thereafter in 
the laboratory. The regression equation between the pilodyn reading and the basic wood density was constructed on these underlying evaluations.

For both traits variance analyses were done for each site and then a joint analysis involving the three sites was performed by using the following model:

$$
\mathrm{Y}_{\mathrm{ijkl}}=\mathrm{m}+\mathrm{t}+\mathrm{b}_{\mathrm{j}(\mathrm{kl})}+\mathrm{r}_{\mathrm{k}(\mathrm{l})}+\mathrm{l}_{\mathrm{l}}+(\mathrm{tl})_{\mathrm{il}}+\mathrm{e}_{(\mathrm{ijkl})}
$$

Where:

$\mathrm{Y}_{\mathrm{ijkl}}$ : is the observed value in the plot that received the $\mathrm{i}^{\text {th }}$ treatment, in the $\mathrm{j}^{\text {th }}$ block, in the $\mathrm{k}^{\text {th }}$ replicate and in the $\mathrm{l}^{\text {th }}$ site;

m: common constant of all observations;

$t_{i(1)}$ : random effect of the $i^{\text {th }}$ treatment (i = 1,2,3,...,196);

$b_{j(k l)}$ : random effect of the $j^{\text {th }}$ block within of the $k^{\text {th }}$ replicate and of the $\mathrm{l}^{\text {th }}$ site $(\mathrm{j}=1,2,3, \ldots, 14)$;

$\mathrm{r}_{\mathrm{k}(\mathrm{l})}$ : random effect of the $\mathrm{k}^{\text {th }}$ replicate within of the $\mathrm{l}^{\text {th }}$ site $(\mathrm{k}=1,2,3, \ldots, 40)$;

$\mathrm{l}_{1}$ : $\quad$ random effect of the $\mathrm{l}^{\text {th }}$ site $(\mathrm{l}=1,2,3)$;

$(\mathrm{tl})_{\mathrm{il}}$ : random effect of the interaction between $\mathrm{i}^{\text {th }}$ treatments and the $1^{\text {th }}$ sites;

$\mathrm{e}_{(\mathrm{ijkl})}$ : experimental error associated with the observation $\mathrm{Y}_{\mathrm{ijkl}}$, with distribution $\mathrm{e}_{(\mathrm{ijkl})} \sim \mathrm{N}\left(0, \sigma^{2}\right)$.

As there were missing plants the statistical analyses were run using the Procedure for Mixed Linear Models (PROC MIXED) of SAS ${ }^{\circledR}$ (SAS Institute InC., 2000). The command solution was used to obtain the predicted genotypic deviations $\left(\tilde{g}_{i}\right)$ of each treatment type from the common constant to all observations. Then the $\tilde{g}_{i}$ were added to this constant to obtain the genotypic values of each treatment (BLUPs). The hybrids performance in relation the parents were obtained by the expression:

$$
\begin{aligned}
& v_{i j}=U G_{i j}-\frac{G_{i}+U_{j}}{2} \\
& \left(v_{i j} \div \frac{G_{i}+U_{j}}{2}\right) \times 100=v_{i j} \%
\end{aligned}
$$

Where:

$\mathrm{UG}_{\mathrm{ij}}$ : genotypic value of the inter-specific full-sib progeny ij;

$\mathrm{G}_{\mathrm{i}}$ and $\mathrm{U}_{\mathrm{j}}$ : genotypic value of the OPi of $E$. grandis and $\mathrm{j}$ of $E$. urophylla, parents of the full-sib progeny ij.

The correlation between the progenies mean across locations were estimated pair wise. At each location, the correlation between the evaluated traits was also obtained (STEEL et al., 1997).

\section{Results and Discussion}

The interactions involving progenies $\mathrm{x}$ locations, despite significant, were of small magnitude. For circumference at breast height, for example, regardless of the progenies origin, the component of interaction accounted for only $8.0 \%$ of that attributed to the progenies. This value was slightly higher for basic wood density, around $12.0 \%$. Similar results regarding the treatments $\mathrm{x}$ locations interaction were obtained in other experiments involving clone evaluation and conducted at the same sites (LIMA et al., 2000; REZENDE and RESENDE, 2001). Likewise, in the evaluation of hybrids in experiments contiguous to these, using one plant per plot, the treatments $\mathrm{x}$ locations interaction was also of small magnitude.

The estimates of correlations between the mean performance of the progenies across sites two by two were, in the most cases, higher than 0.8 (Table 1). This fact indicates that the interaction was predominantly simple (VENCOVSKY and BARRIGA, 1992). It can therefore be expected that it does not modify the progenies ranking expressively. So, the focus of discussions will be directed towards progeny performance at the level of means across sites.

There were significant differences between the evaluated progenies for the two traits. In the decomposition, it was observed that the between progeny variances obtained for the intra-specific OP progenies of $E$. grandis and $E$. urophylla were different from zero. The same

Table 1. - Estimates of correlation between the mean performances of the each type $(\mathrm{G}=E$. grandis open pollinated families; $\mathrm{U}=E$. urophylla open pollinated families;

\begin{tabular}{|c|c|c|c|c|c|c|}
\hline \multirow{3}{*}{ Sites } & \multicolumn{6}{|c|}{$\mathrm{CBH}(\mathrm{cm})$} \\
\hline & \multicolumn{3}{|c|}{ São Mateus } & \multicolumn{3}{|c|}{ Caravelas } \\
\hline & G & $\mathrm{U}$ & GU & G & $\mathrm{U}$ & GU \\
\hline Aracruz & 0,85 & 0,70 & 0,89 & 0,86 & 0,58 & 0,74 \\
\hline \multirow[t]{2}{*}{ São Mateus } & - & - & - & 0,86 & 0,86 & 0,76 \\
\hline & \multicolumn{6}{|c|}{$\mathrm{BWD}\left(\mathrm{kg} \cdot \mathrm{m}^{-3}\right)$} \\
\hline Aracruz & 0,92 & 0,83 & 0,84 & 0,89 & 0,72 & 0,86 \\
\hline São Mateus & - & - & - & 0,96 & 0,87 & 0,94 \\
\hline
\end{tabular}
$\mathrm{GU}=E$. grandis $\times$ $E$. urophylla full sib families) of progeny in pair of sites for the circumference at breast height $(\mathrm{CBH})$ and basic wood density (BWD). 
was verified for the inter-specific progenies. Considering each progeny type separately, the amplitude of variation in relation to the mean, for $\mathrm{CBH}$, was not the same between the sites. At the means level across site, it was $48.5 \%$ for $E$. grandis progenies, $40.6 \%$ for $E$. urophylla progenies and $31.4 \%$ for the full-sib progenies. For BWD on the other hand, the amplitude of variation in relation to the mean was around $10.0 \%$ for the three progeny types (Table 2).

For $\mathrm{CBH}$, the E. urophylla progenies performance was, in average, $31.7 \%$ superior to that obtained for the $E$. grandis progenies. For BWD however, the mean performance of $E$. grandis progenies was similar to that of E. urophylla (Table 2). Nevertheless, were measured young plants. There are little information about that in the literature. In one of these, PEREIRA et al. (2000) reports a greater BWD to $E$. urophylla.

The inter-specific progenies presented a performance $38.7 \%$ higher than the mean of the intra-specific progenies for $\mathrm{CBH}$. On the other hand, for BWD, the genotypic value of the inter-specific progenies was only $1.18 \%$ $(\mathrm{P} \leq 0.01)$ below the genotypic value of the intra-specific progenies (Table 2). The superiority of $E$. grandis $\mathrm{x}$ $E$. urophylla hybrid combinations at meeting the requirements of the cellulose industry with vigorous growth and good wood quality has repeatedly been stated (REZENDE and RESENDE, 2000; Assis, 2000; VERRYN, 2000; Bouvet and Vigneron, 1996; Bertolucci et al., 1995). For this reason, hybrids of these two species have taken into commercial use in several countries such as
Brazil, South Africa, Colombia, Venezuela, and in the Congo (REsEnde, 2002).

The controls used in the experiments were commercial clones of the company, which performed well at the different sites of eucalypt cultivation. This fact was corroborated in our study. The genotypic value of the controls was superior to that of the intra-specific progenies for the two analyzed traits. However, for $\mathrm{CBH}$, the mean performance of the inter-specific progenies was slightly greater than that of the controls (Table 2). The amplitude of variation of full-sib progenies in relation to the mean performance indicates that there is sufficient genetic variability to enable breeders to select individuals that outperform the controls.

The obtained estimates of vigor show superiority of the inter-specific progenies in relation to the intra-specific for $\mathrm{CBH}$ with a variation between them of the $10.0 \%$ to $69.0 \%$. For BWD this variation was close to zero (Table 3).

Therefore, the value of the vigor to represent the heterosis can be overestimated. In the Eucalyptus genus the frequency of self-pollination can vary from $10 \%$ to $30 \%$ (ELDRIDGE et al., 1997). In this way, part of vigor of the hybrids in relation to the mean of the parents could be attributed to the inbreeding depression due the selfing that occurred in the OP progenies. VolKER et al. (1994) and HoDGE et al. (1996) talk too about the influence of the inbreeding depression on the heritability estimates in $E$. globulus. Is so difficult to isolate the effect of inbreeding depression due the selfing of the OP

Table 2. - Means and amplitude of variation (A) for the circumference at breast height $(\mathrm{CBH})$ and basic wood density (BWD) by site.

\begin{tabular}{|c|c|c|c|c|c|c|}
\hline \multirow[b]{3}{*}{ Sites } & \multicolumn{6}{|c|}{$\mathrm{CBH}(\mathrm{cm})$} \\
\hline & \multicolumn{2}{|c|}{ E. grandis } & \multicolumn{2}{|c|}{ E. urophylla } & \multicolumn{2}{|r|}{$\mathrm{GU}$} \\
\hline & Mean & $\mathrm{A}$ & Mean & $\mathrm{A}$ & Mean & $\mathrm{A}$ \\
\hline Aracruz & 20,50 & $7,84(38,24)^{1}$ & 25,90 & $5,93(22,90)$ & 30,38 & $8,77(28,46)$ \\
\hline São Mateus & 22,59 & $12,75(56,44)$ & 30,36 & $15,27(50,30)$ & 37,36 & $12,94(34,63)$ \\
\hline Caravelas & 19,19 & $9,76(50,86)$ & 25,69 & $12,50(48,66)$ & 32,25 & $10,02(31,07)$ \\
\hline Means & 20,75 & $(48,51)$ & 27,32 & $(40,62)$ & 33,33 & $(31,39)$ \\
\hline \multirow[t]{2}{*}{ Controls } & & & & & 31,9 & \\
\hline & \multicolumn{6}{|c|}{ BWD $\left(\mathrm{Kg} \cdot \mathrm{m}^{-3}\right)$} \\
\hline Aracruz & 429,23 & $31,52(7,34)$ & 422,85 & $38,20(9,03)$ & 422,37 & $37,96(8,98)$ \\
\hline São Mateus & 407,91 & $41,68(10,21)$ & 407,42 & $40,33(9,90)$ & 404,32 & $33,06(8,18)$ \\
\hline Caravelas & 393,70 & $53,75(13,65)$ & 391,54 & $40,10(10,24)$ & 385,27 & $52,80(13,70)$ \\
\hline Means & 410,28 & $(10,4)$ & 407,25 & $(9,72)$ & 403,99 & $(10,28)$ \\
\hline Controls & & & & & 420,6 & \\
\hline
\end{tabular}

\footnotetext{
${ }^{1} \mathrm{~A} /$ mean * 100 .
} 
Table 3. - Estimates of vigor (h) of the full-sib progenies between $E$. grandis x $E$. urophylla, in relation to the genotypic value of the open pollinated progenies of $E$. grandis and $E$. urophylla for circumference at breast height $(\mathrm{CBH})$ and basic wood density (BWD) at the age of two years; mean results across the three environments.

\begin{tabular}{|c|c|c|c|c|c|c|c|c|}
\hline \multirow[b]{2}{*}{ Progeny } & \multicolumn{3}{|c|}{$\mathrm{CBH}(\mathrm{cm})$} & \multirow[b]{2}{*}{ h (\%) } & \multicolumn{3}{|c|}{ BWD $\left(\mathrm{kg} \cdot \mathrm{m}^{-3}\right)$} & \multirow[b]{2}{*}{ h (\%) } \\
\hline & $\mathrm{G}^{1 / 1}$ & $U^{1 / 1}$ & $\mathrm{GU}^{\underline{1}}$ & & $\mathrm{G}$ & $\mathrm{U}$ & GU & \\
\hline 1 & 17,02 & 29,23 & 34,45 & 48,93 & 404,81 & 408,20 & 392,17 & $-3,53$ \\
\hline 2 & 21,82 & 30,82 & 34,34 & 30,30 & 392,56 & 393,07 & 390,09 & $-0,69$ \\
\hline 3 & 17,67 & 26,64 & 31,87 & 43,39 & 428,65 & 407,22 & 413,89 & $-0,97$ \\
\hline 4 & 25,65 & 20,57 & 30,69 & 32,51 & 403,91 & 399,05 & 403,69 & 0,55 \\
\hline 5 & 19,26 & 22,31 & 35,01 & 68,84 & 425,29 & 429,40 & 414,23 & $-3,07$ \\
\hline 6 & 18,08 & 27,91 & 31,18 & 34,98 & 418,50 & 417,73 & 421,43 & 0,79 \\
\hline 7 & 17,11 & 23,60 & 29,14 & 44,95 & 419,33 & 414,89 & 411,00 & $-1,46$ \\
\hline 8 & 23,35 & 28,73 & 30,70 & 17,91 & 405,18 & 399,93 & 406,17 & 0,90 \\
\hline 9 & 23,30 & 29,44 & 37,55 & 42,02 & 405,36 & 414,04 & 407,94 & $-0,43$ \\
\hline 10 & 21,30 & 29,21 & 34,52 & 36,42 & 406,09 & 405,65 & 398,76 & $-1,75$ \\
\hline 11 & 23,09 & 26,73 & 34,00 & 36,04 & 396,70 & 394,95 & 400,06 & 1,07 \\
\hline 12 & 16,72 & 27,61 & 33,76 & 51,67 & 434,47 & 404,37 & 409,93 & $-2,26$ \\
\hline 13 & 23,85 & 26,19 & 39,40 & 57,05 & 394,80 & 392,85 & 380,00 & $-3,51$ \\
\hline 14 & 18,54 & 30,40 & 32,96 & 34,61 & 417,16 & 407,96 & 396,88 & $-3,80$ \\
\hline 15 & 24,60 & 30,53 & 30,29 & 10,11 & 401,35 & 419,74 & 413,65 & 0,76 \\
\hline Mean & 20,75 & 27,32 & 33,23 & 38,7 & 410,28 & 407,27 & 403,99 & $-1,16$ \\
\hline
\end{tabular}

progeny from that due the vigor in the cross, however, even if the level of selfing was high in the OP one would not expect inbreeding to explain all of the $38.7 \%$ average difference found between $\mathrm{OP}$ and hybrids material. Results evidenced that dominance occurs in the $\mathrm{CBH}$ expression. For basic wood density on the other hand, since the parents were also divergent, one can infer that the absence of heterosis is due to the absence of dominance in the expression of this trait.
Results found in literature show that heterosis exists for traits associated to plant growth, also evidencing the occurrence of dominance in the genetic control of wood volume (REZENDE and RESENDE, 2000; Bouvet and VignERON, 1996). Heterosis has however not been detected for wood density (Assis, 2000). These results agree with those obtained in the present study. In relation to the estimates of inbreeding depression for the two traits our results were also concordant with others.

Table 4. - Estimates of the genetic correlations $\left(\mathrm{r}_{\mathrm{G}}\right)$ between circumference at breast height $(\mathrm{CBH})$ and basic wood density (BWD) in the evaluation of half-sib progenies of $E$. grandis and $E$. urophylla, and full-sib progenies between the two species, at the age of two years.

\begin{tabular}{ccccccccc}
\hline \multicolumn{2}{c}{ Aracruz } & \multicolumn{2}{c}{ São Mateus } & \multicolumn{2}{c}{ Caravelas } & \multicolumn{2}{c}{ Joint analysis } \\
\hline $\mathrm{r}_{\mathrm{G}}$ & $\mathrm{P}^{\underline{1}}$ & $\mathrm{r}_{\mathrm{G}}$ & $\mathrm{P}$ & $\mathrm{r}_{\mathrm{G}}$ & $\mathrm{P}$ & $\mathrm{r}_{\mathrm{G}}$ & $\mathrm{P}$ \\
\hline$-0,57$ & 0,00 & $-0,39$ & 0,00 & $-0,50$ & 0,00 & $-0,50$ & 0,00
\end{tabular}

${ }^{1 /}$ probability value (type I error) for $\mathrm{t}$ test. 
Using elite clones of the Aracruz Celulose S. A., the estimate of the inbreeding depression to self versus parent clones was, in the mean, $17.0 \%$ for $\mathrm{CBH}$ and only $4.0 \%$ for BWD (BISON et al., 2004).

Apart from the occurrence of epistasis, the mean performance of a hybrid is function of the parents mean, of the contribution of the loci in homozygosis and also of heterosis. So the performance per se of the parents is not sufficient to obtain good hybrid combinations. Correlations between the mean of parents based on OP and hybrids were 0.22 for $\mathrm{CBH}$ and 0.77 for BWD (results not shown). Correlations between the performance per se of parents and hybrids in Eucalyptus were not found in literature. Still, no association has been found for maize between the performance per se of lines and hybrids derived thereof (BERNARDO, 2002). These results show the need to obtain hybrid combinations and identify the most promising among them.

The existence of vigor for $\mathrm{CBH}$ but not for $\mathrm{BWD}$ implies that forest tree breeders have to use different strategies for the improvement of these two traits. In this case, there is an additional drawback - the negative correlation between $\mathrm{CBH}$ and $\mathrm{BWD}$, despite not of great magnitude (Table 4). An alternative to improve simultaneous two traits would be establishing a selection index (BERNARDO, 2002). Another alternative would be the use of independent selection levels (FALCONER and MACKAY, 1996). In other words, only progenies and or individuals with greater circumference at breast height that present the minimal acceptable density by the cellulose industry would be selected. In this situation the negative correlation would be less important.

The use of these combinations to get new clones in the company will surely provide genetic gains that exceed the reported ones. The best alternative for selection of best individuals would be based on predicted genotypic values of each one, using the mixed model methodology (RESENDE, 2002). In this case, the best individuals could be selected by the individual BLUP methodology, considering all evaluated full-sib progenies, which would make the application of very high selection intensity, since around 7.000 inter-specific hybrid trees were evaluated.

\section{Conclusions}

The presence of heterosis for circumference at breast height was high, an average, $38.7 \%$ than the OP progenies for both species. Part of the heterosis in relation to parental means could be attributed to the inbreeding depression due to selfing that occurred in the OP progenies and the dominance controlling this character.

As the vigor was practically zero for basic wood density and there was divergence between the parents it was concluded that the allelic interaction of dominance is less important for this trait.

\section{Acknowledgements}

The authors thanks the CNPq for the scholarship and Aracruz Celulose S.A. for the opportunity to develop this study in the company.

\section{References}

Assis, T. F. DE (2000): Production and use of Eucalyptus hybrids for industrial purposes. Symposium on hybrid breeding and genetics of forest trees, Noosa, QFRI. Australia, 63-74.

BERNARDO, R. (2002): Breeding for quantitative traits in plants. Woodbury, Minnesota: 369p. Stemma Press.

Bertolucci, F. De L. G., G. D. S. P. Rezende and R. PANChel (1995): Produção e utilização de híbridos de eucalipto. Silvicultura 26, 12-16.

Bison, O., A. M. Aguiar, G. D. S. P. Rezende and M. A. P. Ramalho (2004): Inbreeding depression in Eucalyptus clones. Crop breeding and applied biotechnology 4: 459-464.

Bouvet, J. M. and P. Vigneron (1996): Variance structure in Eucalyptus hybrid populations. Silvae Genetica 45, 171-177.

EldRIDGe, K., I. Davidson, C. HARWood and G. VAN WYK (1993): Eucalypt domestication and breeding. Oxford University Press, New York, 288p.

FALCONER, D. S. and T. F. C. MACKAY (1996): Introduction to quantitative genetics. London: Longman Malaysia.

Hodge, G. R., P. W. Volker, B. M. Potts and J. V. Owen (1996): A comparison of genetic information from openpollinated and control pollinated progeny tests in two Eucalyptus species. TAG. 92: 53-63.

Lima, J. T., M. C. Breese and C. M. CAhalan (2000): Genotype-environment interaction in wood basic density of Eucalyptus clones. Wood Science and Technology 34: 197-206.

Pereira, J. C. D., J. A. Sturion, A. R. Higa, R. C. V. Higa and J. Y. SHIMizu (2000): Características da madeira de algumas espécies de eucalipto plantadas no Brasil, Colombo in Embrapa Florestas (Embrapa Florestas. Documentos, 38), Brasília/BR.

RESENDE, M. D. V. DE (2002): Genética biométrica e estatística: no melhoramento de plantas perenes. Embrapa Informação Tecnológica,Brasília, Brasil.

Rezende, G. D. S. P. and M. D. V. DE Resende (2000): Dominance effects in Eucalyptus grandis, Eucalyptus urophylla and hybrids. Symposium on hybrid breeding and genetics of forest trees, Noosa, QFRI. Australia, 93-100.

Rezende, G. D. S. P. and M. D. V. DE Resende (2001): Genotypic evaluation and genotype $\mathrm{x}$ environment interaction in Eucalyptus clones selection at Aracruz Celulose S. A., Brazil. In: Iufro International Symposium: Developing the Eucalypt of the Future, 2001, Valdivia. Proceedings. Valdivia: Instituto Forestal - Chile, 2001. v. 1. p. 69-81.

SAS Institute (2000): SAS: User's Guide Statistical (version 8.0.) ed. Cary, NC.

Steel, R. G. D., J. H. Torrie and D. A. Dickey (1997): Principles and procedures of statistics: a biometrical approach, 3. ed., Mc Graw-Hill Book Company, New York.

VEnCOVsKY, R. and P. BARRIGA (1992): Genética biométrica no fitomelhoramento. Sociedade Brasileira de Genética, Ribeirão Preto, Brasil.

VERRYN, S. D. (2000): Eucalyptus hybrid breeding in South Africa. Symposium on hybrid breeding and genetics of forest trees, Noosa, QFRI. Australia, 191-199 p.

VolKer, P. W., J. V. Owen and N. M. G. BorRAlHo (1994): Genetics variances and covariances for frost tolerance in Eucalyptus globulus and E. nitens. Silvae Genetics 43(5/6), 366-372. 